\title{
Hemodynamic effects of local anesthetics intoxication. Experimental study in swine with levobupivacaine and bupivacaine ${ }^{1}$
}

\author{
Efeitos hemodinâmicos da intoxicação com anestésicos locais. Estudo experimental \\ em suínos com levobupivacaína e bupivacaína
}

\author{
Artur Udelsmann', Sílvia Elaine Rodolfo de Sá Lorena ${ }^{I I}$, Samira Ubaid Girioli'II, William Adalberto Silva ${ }^{\text {IV }}$, Ana \\ Cristina de Moraes $^{\mathrm{IV}}$, Nelson Adami Andreollo ${ }^{\mathrm{V}}$ \\ I Assistant Professor, Department of Anesthesiology, Laboratory of Experimental Anesthesia, Center for Experimental Medicine and \\ Surgery, School of Medicine, UNICAMP, Campinas, São Paulo, Brazil. \\ II Fellow Master degree, Department of Surgery, UNICAMP, Campinas, São Paulo, Brazil. \\ III Fellow Master degree, Department of Pharmacology, UNICAMP, Campinas, São Paulo, Brazil. \\ IV Biologist, Center for Medicine and Experimental Surgery, UNICAMP, Campinas, São Paulo, Brazil. \\ V Full Professor, Head Department of Surgery, UNICAMP, Campinas, São Paulo, Brazil
}

\begin{abstract}
Purpose: To compare the hemodynamic repercussions following a toxic dose of levobupivacaine and bupivacaine intravascularly injected in swines. Methods: Large White pigs were anesthetized with thiopental, tracheal intubation was performed and mechanical ventilation was instituted. Hemodynamic variables were recorded with invasive pressure monitoring and pulmonary artery catheterization (Swan-Ganz catheter). After a 30-minute resting period, the animals were randomly divided into two groups in a double-blinded fashion and received a bolus injection of $4 \mathrm{mg} / \mathrm{kg}$ of either agent for intoxication. Hemodynamic results were then evaluated at 1, 5, 10, 15, 20 and 30 minutes. Results: Levobupivacaine had greater hemodynamic repercussions than racemic bupivacaine. These results disagree with those found when the levorotatory isomer of bupivacaine was used in humans, but are in agreement with recently reported findings in animals. Conclusion: Levobupivacaine was shown to be more toxic in pigs than racemic bupivacaine when large doses are injected intravenously.
\end{abstract}

Key words: Bupivacaine. Anesthesia, Local. Swine.

\section{RESUMO}

Objetivo: Comparar as repercussões hemodinâmicas da levobupivacaína e bupivacaína após uma dose tóxica intravascular em suínos. Métodos: Porcos Large-White foram anestesiados com tiopental, entubados e mantidos em ventilação controlada mecânica. Parâmetros hemodinâmicos foram registrados através de pressão invasiva e cateterização da artéria pulmonar (cateter de Swan-Ganz). Após 30 minutos de repouso, os animais foram divididos aleatoriamente em dois grupos e receberam injeção endovenosa em duplo-cego de $4 \mathrm{mg} / \mathrm{kg}$ de um ou outro agente anestésico simulando uma intoxicação. Foram avaliados resultados hemodinâmicos aos 1, 5, 10, 15, 20 e 30 minutos. Resultados: Levobupivacaína teve maiores repercussões hemodinâmicas que a bupivacaína racêmica. Estes resultados discordam daqueles encontrados com o isômero levógiro em humanos, mas estão de acordo com resultados recentemente informados em animais. Conclusão: Levobupivacaína mostrou ser agente mais tóxico em suínos do que a bupivacaína racêmica quando grandes doses são injetadas por via intravascular.

Descritores: Bupivacaína. Anesthesia, Local. Suínos.

1. Research performed at Laboratory of Experimental Anesthesia, Center for Medicine and Experimental Surgery, School of Medicine, State University of Campinas (UNICAMP), São Paulo, Brazil. 


\section{Introduction}

High doses of local anesthetic agents are sometimes required for surgery following the administration of local and regional anesthesia and there is always the potential risk for toxic reactions. Both the cardiovascular and central nervous systems are the primary target organs of local anesthetic toxicity in case of inadvertent intravascular injection. Bupivacaine is currently one of the most widely used local anesthetics, due to its quality of anesthesia and prolonged duration of action. ${ }^{1,2}$ Nevertheless, an Anesthesiology editorial on the severe cardiovascular effects of bupivacaine intoxication was published in $1979,{ }^{3}$ and since then research has focused on discovering new longacting local anesthetics with lower toxicity. Although bupivacaine is synthesized in the form of its two dextrorotatory $\mathrm{R}(+)$ and levorotatory $\mathrm{L}(-)$ isomers ${ }^{4}$, until recently it had only been marketed as a racemic mixture, containing $50 \%$ of each of the two enantiomers. However, evidence that the levorotatory isomer caused less toxicity dates back to $1972 .{ }^{5,6}$ Levobupivacaine, the levorotatory isomer, has recently begun to be more widely studied. In some animal models, the lethal dose of levobupivacaine was shown to be up to 1.6 times higher than that of the racemic mixture ${ }^{7}$ ! In humans, levobupivacaine would be less potent at producing negative inotropic effects and prolonging the PR and QT intervals of the ECG, typical of racemic mixture intoxication ${ }^{8}$. However, the drawback with this new agent would be its less intense motor block ${ }^{10}$, despite having equal analgesic potency to racemic bupivacaine. ${ }^{9}$ The aim of this study was to simulate acute intoxication with either agent in pigs, as might accidentally occur during local and regional anesthesia with high doses of local anesthetics and to evaluate its hemodynamic repercussions.

\section{Methods}

After approval from the Ethics Committee for Animal Experiments, forty healthy Large White pigs (both sexes, body weight $20-27 \mathrm{~kg}$ ) underwent the following protocol:

1. The pigs were fasted on the night before the procedure and had free access to water.

2. In the morning of the procedure, they were weighed, an auricular vein was cannulated and anesthesia was induced with a $25 \mathrm{mg} . \mathrm{kg}^{-1} \mathrm{IV}$ dose of sodium thiopental $2.5 \%$ solution ${ }^{11}$.

3. The body surface area of the animal (BSA) was calculated in square meters using the classic formula from the literature ${ }^{12}: \mathrm{BSA}=\left(9 \times\right.$ weight in grams $\left.{ }^{2 / 3}\right) \times 10^{-4}$, introducing the value into the Engstrom $\mathrm{AS} / 3$ multiparametric monitor for calculation of body index values.

4. A tracheal tube was inserted and connected to a pneumatically driven ventilator using a partial re-breathing system and $\mathrm{CO}_{2}$ absorbent. Tidal volume was $15 \mathrm{ml} . \mathrm{kg}^{-1}$ and respiratory rate was adjusted to maintain $\mathrm{ETCO}_{2}$ at $32-34$ $\mathrm{mmHg}$. Fresh oxygen flow was $1 \mathrm{l} / \mathrm{min}$ and hemoglobin oxygen saturation was measured, placing the sensor on the animal tongue, aimed at achieving a value above $97 \%$. ECG was also monitored.
5. Anesthesia was maintained with an intravenous infusion of sodium thiopental $2.5 \%\left(5 \mathrm{mg} \cdot \mathrm{kg}^{-1} \cdot \mathrm{h}^{-1}\right)$.

6. Subsequently, an incision was made along the inner aspect of the thigh under local anesthesia $(5 \mathrm{ml} 1 \%$ lidocaine hydrochloride without vasoconstrictor) for catheterization of the femoral artery and continuous measurement of arterial blood pressure. Through the same incision, the femoral vein was dissected and a 7F SwanGanz catheter was inserted. The catheter was advanced into a branch of a pulmonary artery and proper catheter placement was confirmed by the pressure waveform obtained. Cardiac output (CO) was then measured by the thermodilution method. In addition, mean arterial pressure (MAP), mean pulmonary artery pressure (mPAP), central venous pressure (CVP) and pulmonary capillary wedge pressure (PCWP) were measured. Using classic formulas in the literature, the monitor also performed calculations of the remaining hemodynamic parameters, e.g.: cardiac index (CI), stroke index (SI), systemic vascular resistance index (SVRI), pulmonary vascular resistance pulmonary index (PVRI), left ventricular stroke work index (LVSWI), right ventricular stroke work index (RVSWI). At this early phase, blood samples were drawn from the animals for dosage of hematocrit and hemoglobin levels.

7. After a resting period of about 30 minutes to ensure stabilization, baseline hemodynamic measurements $\left(\mathrm{T}_{0}\right)$ were recorded.

8 . Then the animals were randomly divided into 2 groups in a double-blinded fashion: bupivacaine group (B) and levobupivacaine group (L). Each group was intravenously injected with a toxic dose of $4 \mathrm{mg} \cdot \mathrm{kg}^{-1}$ of either local anesthetic ${ }^{13}$ during 30 seconds and the experimenter was blinded to the study code.

11. Additional hemodynamic measurements were recorded at 1, 5, 10, 15, 20 and 30 minutes after intoxication (at $\mathrm{T}_{1}$ to $\mathrm{T}_{6}$, respectively).

12. At the completion of the experiment, each animal was sacrificed while under anesthesia by a $10 \mathrm{ml}$ intravenous injection of $19.1 \%$ potassium chloride solution.

Subsequently, the double-blinded protocol was disclosed and data was statistically treated. Categorical variables received statistical treatment using the chi-square test. Variables without normal distribution were logtransformed for the tests in order to reduce skewness and variability. To compare the distribution of single numerical variables (measured at a single time point), the Student's ttest was used. To study the behavior of the hemodynamic parameters measured at several time points, analysis of variance (ANOVA) for repeated measures was performed, followed by Duncan's post-hoc test for multiple comparisons to compare the groups at each time point (between groups comparisons), and by the profile test by contrasts to analyze the changes in the parameters of each group (within groups comparisons). The significance level was set at $5 \%$, i.e., $\mathrm{p} \leq 0.05$.

\section{Results}

The following table demonstrates the distribution by sex, mean and standard deviations of 
weight, hematocrit levels, hemoglobin levels and body surface areas found in both groups.

\begin{tabular}{lll}
\hline Group & B & L \\
\hline Male & 13 & 14 \\
Female & 7 & 6 \\
Weight & $22.7 \pm 1.87$ & $22.7 \pm 2.75$ \\
$\mathrm{Ht}$ & $29.87 \pm 2.04$ & $29.27 \pm 2.75$ \\
$\mathrm{Hb}$ & $10 \pm 0.74$ & $9.61 \pm 0.74$ \\
BSA & $0.71 \pm 0.04$ & $0.71 \pm 0.06$ \\
\hline
\end{tabular}

The groups were homogeneous regarding distribution by $\operatorname{sex}(\mathrm{p}=0.736)$, weight $(\mathrm{p}=1)$, hematocrit level $(\mathrm{p}=0.334)$, hemoglobin level $(\mathrm{p}=0.099)$ and body surface area $(\mathrm{p}=0.95)$. There was no difference in any of the hemodynamic parameters measured at rest between the groups.
Following intoxication, there was a reduction in cardiac index (Figure 1 and Table 1) in both groups and these values did not return to those similar to resting values until the end of the experiment $(p<0.001)$. The decrease in $\mathbf{L}$ was statistically more important than in $\mathbf{B}$ and was maintained until $\mathrm{T}_{4}(\mathrm{p}<0.001)$.

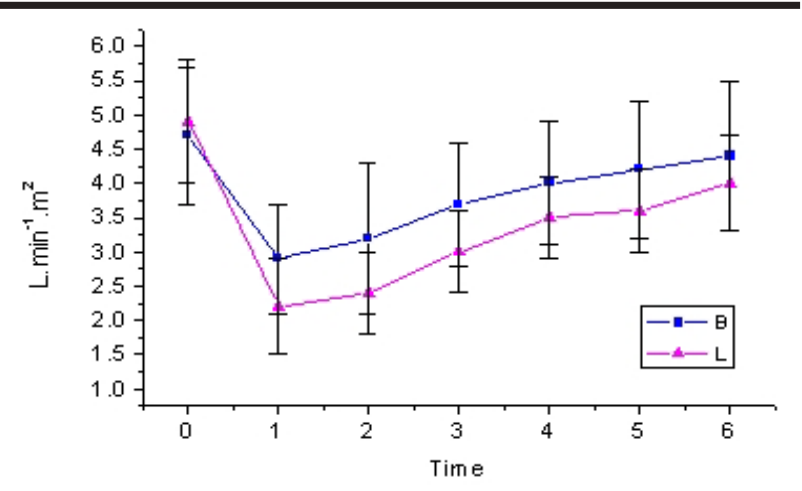

FIGURE 1 - Cardiac

TABLE 1 - Cardiac index $1 . \mathrm{min}^{-1} \cdot \mathrm{m}^{2}$

\begin{tabular}{llllllll}
\hline & $\mathrm{T}_{0}$ & $\mathrm{~T}_{1}$ & $\mathrm{~T}_{2}$ & $\mathrm{~T}_{3}$ & $\mathrm{~T}_{4}$ & $\mathrm{~T}_{5}$ & $\mathrm{~T}_{6}$ \\
$\mathrm{~B}$ & $3.4 \pm 0.8$ & $2.1 \pm 0.6$ & $2.3 \pm 0.8$ & $2.7 \pm 0.7$ & $2.9 \pm 0.7$ & $3.1 \pm 0.8$ & $3.2 \pm 0.9$ \\
$\mathrm{~L}$ & $3.5 \pm 0.9$ & $1.6 \pm 0.5$ & $1.7 \pm 0.5$ & $2.1 \pm 0.5$ & $2.5 \pm 0.6$ & $2.6 \pm 0.5$ & $2.9 \pm 0.6$ \\
\hline
\end{tabular}

Mean arterial pressure (Figure 2 and Table 2) decreased significantly in both groups; values returned to those similar to resting values at $\mathrm{T}_{3}$ in group $\mathbf{B}$ and at $\mathrm{T}_{4}$ $(p<0.001)$ in group L. Starting from $T_{1}$ values in $\mathbf{L}$ were significantly lower than those in $\mathbf{B}$ until $\mathrm{T}_{4}(\mathrm{p}<0.001)$.

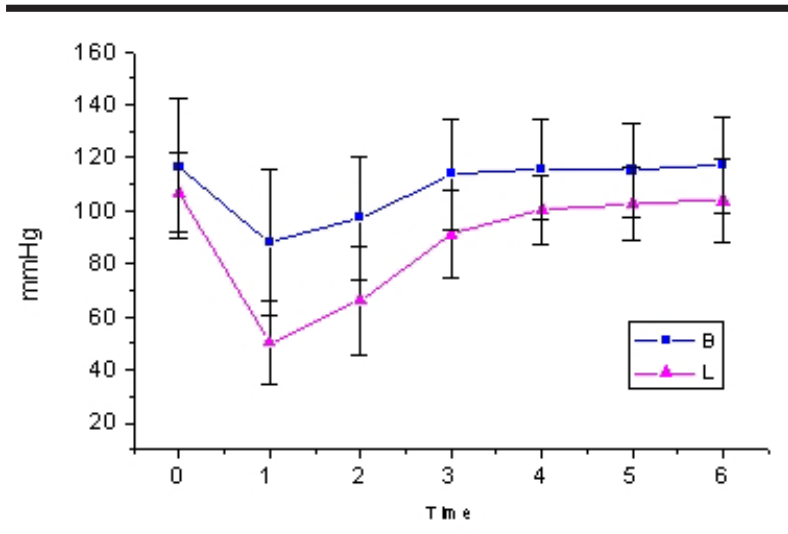

FIGURE 2 - Mean Arteria

TABLE 2 - Mean arterial pressure $\mathrm{mmHg}$

$\begin{array}{cccccccc} & \mathrm{T}_{0} & \mathrm{~T}_{1} & \mathrm{~T}_{2} & \mathrm{~T}_{3} & \mathrm{~T}_{4} & \mathrm{~T}_{5} & \mathrm{~T}_{6} \\ \mathrm{~B} & 3.4 \pm 0.8 & 2.1 \pm 0.6 & 2.3 \pm 0.8 & 2.7 \pm 0.7 & 2.9 \pm 0.7 & 3.1 \pm 0.8 & 3.2 \pm 0.9 \\ \mathrm{~L} & 3.5 \pm 0.9 & 1.6 \pm 0.5 & 1.7 \pm 0.5 & 2.1 \pm 0.5 & 2.5 \pm 0.6 & 2.6 \pm 0.5 & 2.9 \pm 0.6\end{array}$


There was a significant decrease in heart rate (Figure 3 and Table 3 ) following intoxication in both groups, although the reduction was more considerable in $\mathbf{E}$ and this difference was maintained until the end of the experiment $(p<0.001)$. In both groups, HR did not return to values comparable to resting values until $\mathrm{T}_{6}(\mathrm{p}=0.003)$.

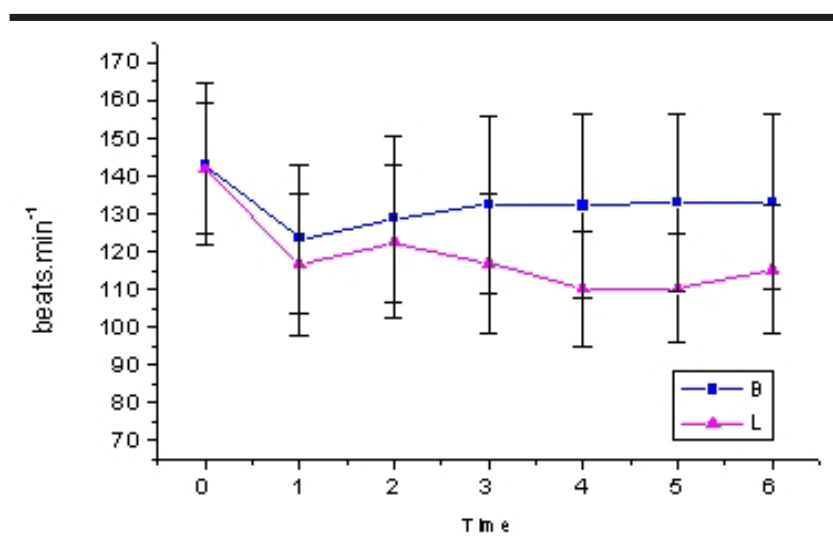

FIGURE 3 - Heart Rate

TABLE 3 - Heart rate beats. min $^{-1}$

\begin{tabular}{cccccccc}
\hline & $\mathrm{T}_{0}$ & $\mathrm{~T}_{1}$ & $\mathrm{~T}_{2}$ & $\mathrm{~T}_{3}$ & $\mathrm{~T}_{4}$ & $\mathrm{~T}_{5}$ & $\mathrm{~T}_{6}$ \\
$\mathrm{~B}$ & $143.1 \pm 21.4$ & $123.3 \pm 19.8$ & $128.6 \pm 22.1$ & $132.3 \pm 23.5$ & $132 \pm 24$ & $133 \pm 23.5$ & $132.9 \pm 23.1$ \\
$\mathrm{~L}$ & $141.9 \pm 17.4$ & $116.6 \pm 18.7$ & $122.5 \pm 20.2$ & $116.8 \pm 18.6$ & $110.1 \pm 15.1$ & $10.2 \pm 14.4$ & $115.3 \pm 16.7$ \\
\hline
\end{tabular}

Central venous pressure (Figure 4 and Table 4) maintained until the end of the experiment $(p<0.001)$ with increased significantly in both groups and the increase was no difference between the groups.

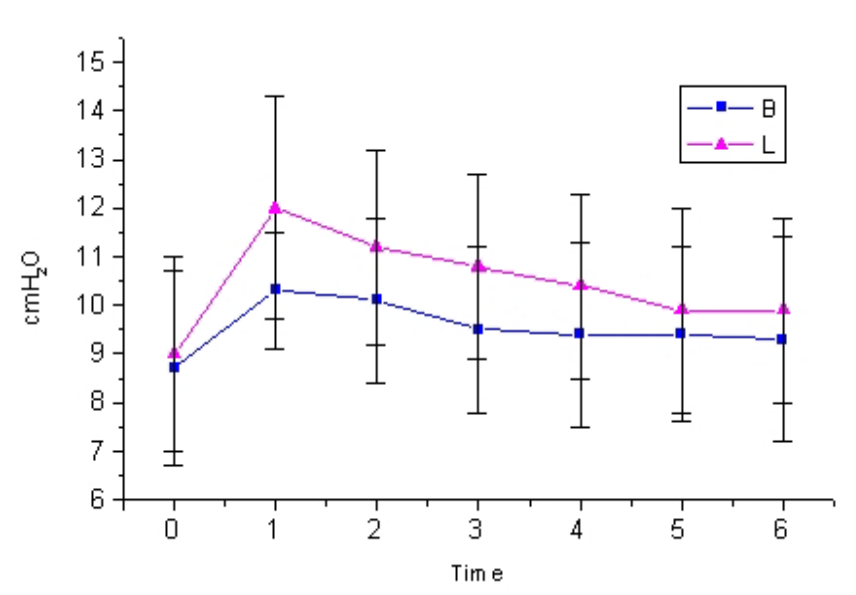

FIGURE 4 - Central Venous Pressure

TABLE 4 - Central venous pressure $\mathrm{cmH}_{2} \mathrm{O}$

\begin{tabular}{llllllll}
\hline & $\mathrm{T}_{0}$ & $\mathrm{~T}_{1}$ & $\mathrm{~T}_{2}$ & $\mathrm{~T}_{3}$ & $\mathrm{~T}_{4}$ & $\mathrm{~T}_{5}$ & $\mathrm{~T}_{6}$ \\
$\mathrm{~B}$ & $8.7 \pm 2$ & $10.3 \pm 1.2$ & $10.1 \pm 1.7$ & $9.5 \pm 1.7$ & $9.4 \pm 1.9$ & $9.4 \pm 1.8$ & $9.3 \pm 2.1$ \\
$\mathrm{~L}$ & $9 \pm 2$ & $12 \pm 2.3$ & $11.2 \pm 2$ & $10.8 \pm 1.9$ & $10.4 \pm 1.9$ & $9.9 \pm 2.1$ & $9.9 \pm 1.9$ \\
\hline
\end{tabular}


5) showed no significant alterations or differences between both groups.

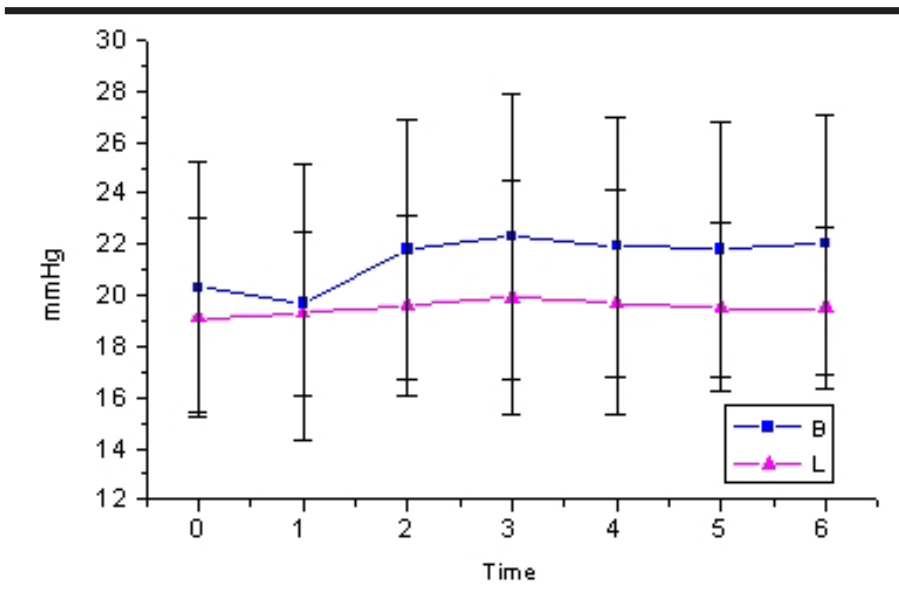

FIGURE 5 - Mean Pulmonary Arterial Pressure

TABLE 5 - Mean pulmonary artery pressure $\mathrm{mmHg}$

\begin{tabular}{llllllll}
\hline & $\mathrm{T}_{0}$ & $\mathrm{~T}_{1}$ & $\mathrm{~T}_{2}$ & $\mathrm{~T}_{3}$ & $\mathrm{~T}_{4}$ & $\mathrm{~T}_{5}$ & $\mathrm{~T}_{6}$ \\
$\mathrm{~B}$ & $20.3 \pm 4.9$ & $19.7 \pm 5.4$ & $21.8 \pm 5.1$ & $22.3 \pm 5.6$ & $21.9 \pm 5.1$ & $21.8 \pm 5$ & $22 \pm 5.1$ \\
$\mathrm{~L}$ & $19.1 \pm 3.9$ & $19.3 \pm 3.2$ & $19.6 \pm 3.5$ & $19.9 \pm 4.6$ & $19.7 \pm 4.4$ & $19.5 \pm 3.3$ & $19.5 \pm 3.2$ \\
\hline
\end{tabular}

Pulmonary capillary wedge pressure (figure and table 6) showed increased values in both groups following intoxication and these values were maintained until the end of the experiment $(p<0.001)$. No difference between the groups was found.

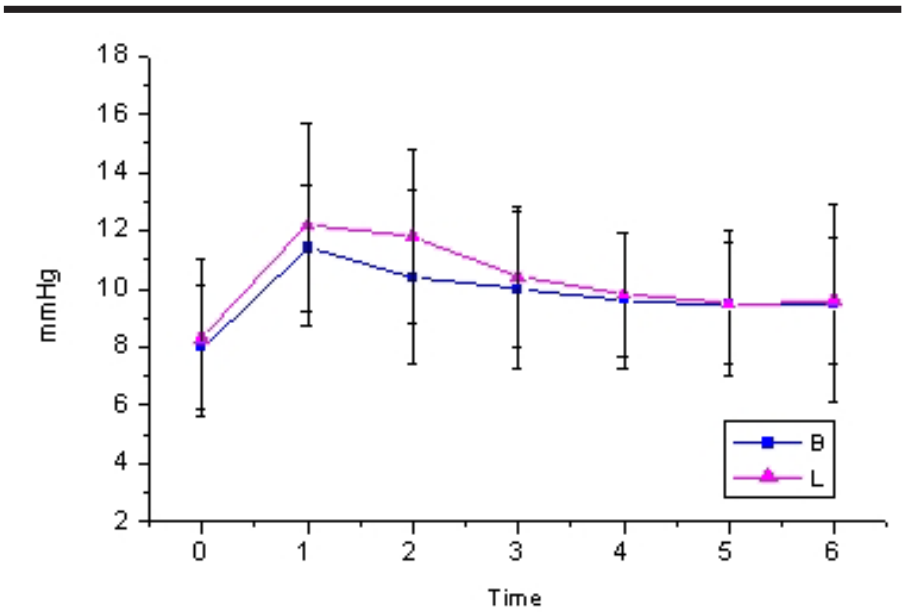

FIGURE 6 - Pulmonary Capillary

TABLE 6 - Pulmonary capillary wedge pressure $\mathrm{mmHg}$

$\begin{array}{llllllll} & \mathrm{T}_{0} & \mathrm{~T}_{1} & \mathrm{~T}_{2} & \mathrm{~T}_{3} & \mathrm{~T}_{4} & \mathrm{~T}_{5} & \mathrm{~T}_{6} \\ \mathrm{~B} & 8 \pm 2.1 & 11.4 \pm 2.2 & 10.4 \pm 3 & 10 \pm 2.7 & 9.6 \pm 2.3 & 9.5 \pm 2.5 & 9.5 \pm 3.4 \\ \mathrm{~L} & 8.3 \pm 2.7 & 12.2 \pm 3.5 & 11.8 \pm 3 & 10.4 \pm 2.4 & 9.8 \pm 2.1 & 9.5 \pm 2.1 & 9.6 \pm 2.2\end{array}$


Stroke index (figure and table 7) demonstrated a significant decline. In both groups, these values remained lower than resting values until $\mathrm{T}_{4}(\mathrm{p}<0.001)$. The fall in $\mathbf{L}$, however, was significantly more important at $\mathrm{T}_{1}$ and $\mathrm{T}_{2}$ $(\mathrm{p}=0.019)$.

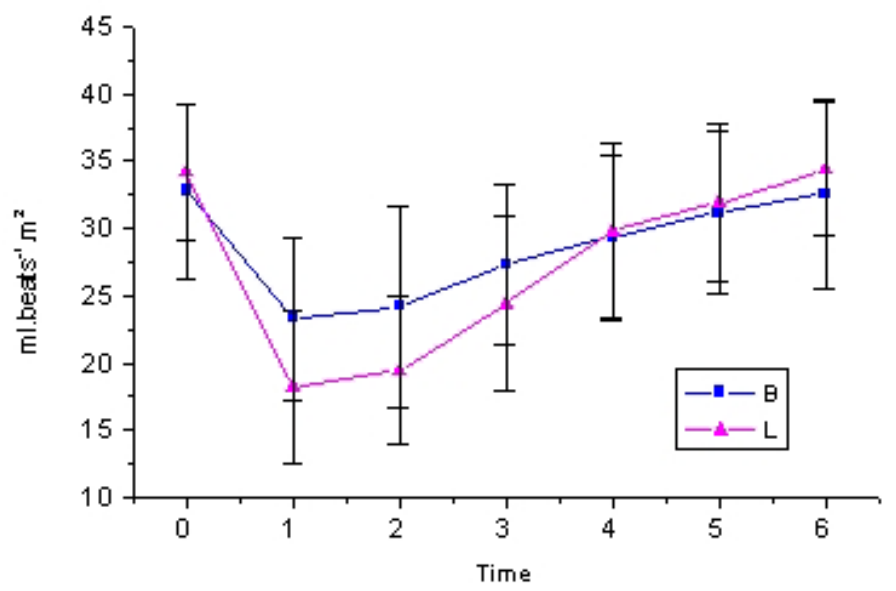

FIGURE 7 - Stroke Index

TABLE 7 - Stroke index ml.beats ${ }^{-1} \cdot \mathrm{m}^{2}$

\begin{tabular}{llllllll}
\hline & & & & & & \\
$\mathrm{T}$ & $\mathrm{T}_{1}$ & $\mathrm{~T}_{2}$ & $\mathrm{~T}_{3}$ & $\mathrm{~T}_{4}$ & $\mathrm{~T}_{5}$ & $\mathrm{~T}_{6}$ \\
$\mathrm{~B}$ & $32.8 \pm 6.5$ & $23.3 \pm 6$ & $24.2 \pm 7.5$ & $27.3 \pm 6$ & $29.4 \pm 6.1$ & $31.2 \pm 6$ & $32.6 \pm 7$ \\
$\mathrm{~L}$ & $34.2 \pm 5$ & $18.2 \pm 5.7$ & $19.4 \pm 5.5$ & $24.4 \pm 6.5$ & $29.8 \pm 6.6$ & $31.9 \pm 5.9$ & $34.4 \pm 5$ \\
\hline
\end{tabular}

Systemic vascular resistance index (figure and table 8) in group B increased, maintaining values higher than resting values until $\mathrm{T}_{6}$. In $\mathbf{L}, \mathrm{SVRI}$ initially showed a decrease followed by a significant increase beginning at $T_{2}$ and maintained values higher than resting values until $\mathrm{T}_{6}$ $(p<0.001)$. B values were higher than $\mathbf{L}$ values at $T_{1}$ and $T_{2}$ $(p=0.004)$.

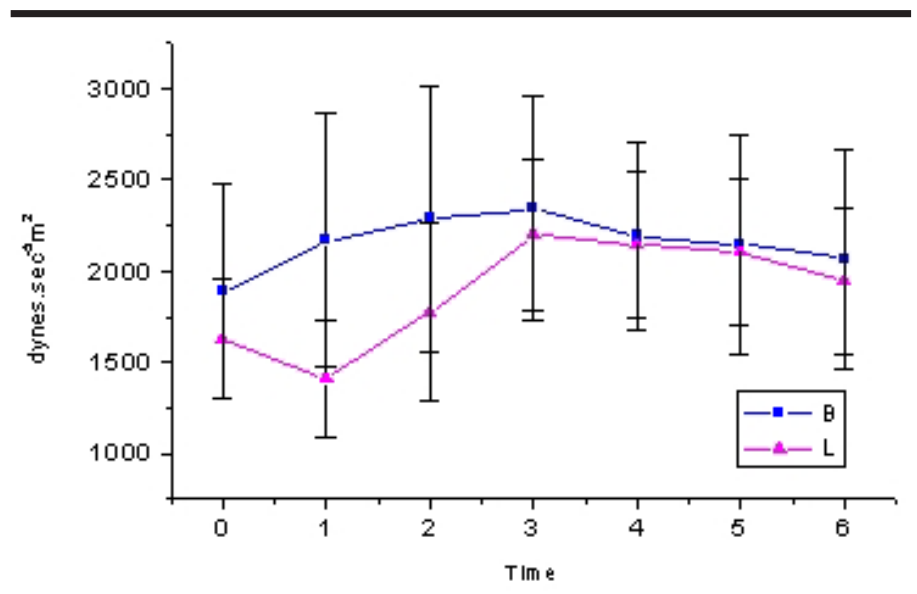

FIGURE 8 - Systemic Vascular Resistance Index

TABLE 8 - Systemic vascular resistance index dynes. $\sec ^{-5} \cdot \mathrm{m}^{2}$

\begin{tabular}{llllllll}
\hline & $\mathrm{T}_{0}$ & $\mathrm{~T}_{1}$ & $\mathrm{~T}_{2}$ & $\mathrm{~T}_{3}$ & $\mathrm{~T}_{4}$ & $\mathrm{~T}_{5}$ & $\mathrm{~T}_{6}$ \\
$\mathrm{~B}$ & $1891 \pm 582.8$ & $2170 \pm 693.9$ & $2285 \pm 733.3$ & $2340 \pm 616$ & $2192 \pm 517.5$ & $2147 \pm 599.3$ & $2067 \pm 601.6$ \\
$\mathrm{~L}$ & $1626 \pm 326.9$ & $1409 \pm 314.8$ & $1776 \pm 485.8$ & $2199 \pm 409$ & $2146 \pm 398.6$ & $2106 \pm 402.8$ & $1945 \pm 399$ \\
\hline
\end{tabular}


Pulmonary vascular resistance index (figure and table 9) showed values higher than resting values from $\mathrm{T}_{2}$ to $T_{5}$ in both groups $(\mathrm{p}=0.001)$ No difference was found between $\mathbf{B}$ and $\mathbf{L}$.

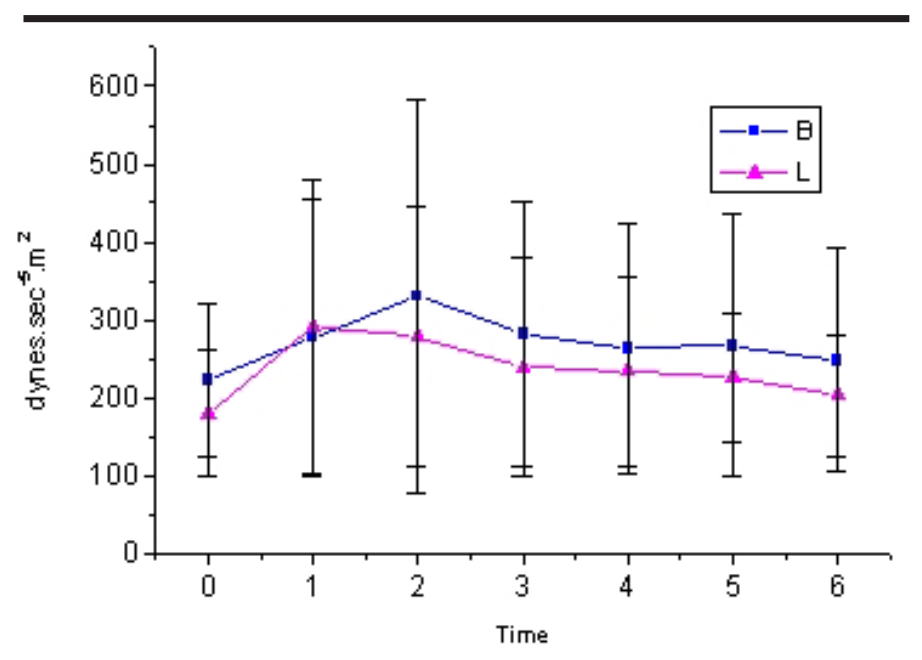

FIGURE 9 - Pulmonary Vascular Resistance Index

TABLE 9 - Pulmonary vascular resistance index dynes. $\mathrm{sec}^{-5} \cdot \mathrm{m}^{2}$

\begin{tabular}{llllllll}
\hline & $\mathrm{T}_{0}$ & $\mathrm{~T}_{1}$ & $\mathrm{~T}_{2}$ & $\mathrm{~T}_{3}$ & $\mathrm{~T}_{4}$ & $\mathrm{~T}_{5}$ & $\mathrm{~T}_{6}$ \\
$\mathrm{~B}$ & $222.6 \pm 99.5$ & $277.2 \pm 177.4$ & $330.6 \pm 252.8$ & $281.2 \pm 170.4$ & $263.1 \pm 160.9$ & $266.6 \pm 169.1$ & $247.9 \pm 143.4$ \\
$\mathrm{~L}$ & $179.7 \pm 80.6$ & $292.1 \pm 189$ & $278.2 \pm 165.9$ & $239.2 \pm 139.9$ & $233.9 \pm 121.5$ & $226.1 \pm 83.3$ & $202.6 \pm 78.5$ \\
\hline
\end{tabular}

Left ventricular stroke work index (figure and table 10) showed a decrease after intoxication in both groups. However, the fall was more significant in $\mathbf{L}$, and this difference was maintained until $\mathrm{T}_{3}(\mathrm{p}=0.001)$. Values returned to those similar to resting values at $T_{4}$ in group $\mathbf{B}$ and $T_{5}$ $(p<0.001)$ in group $\mathbf{L}$.

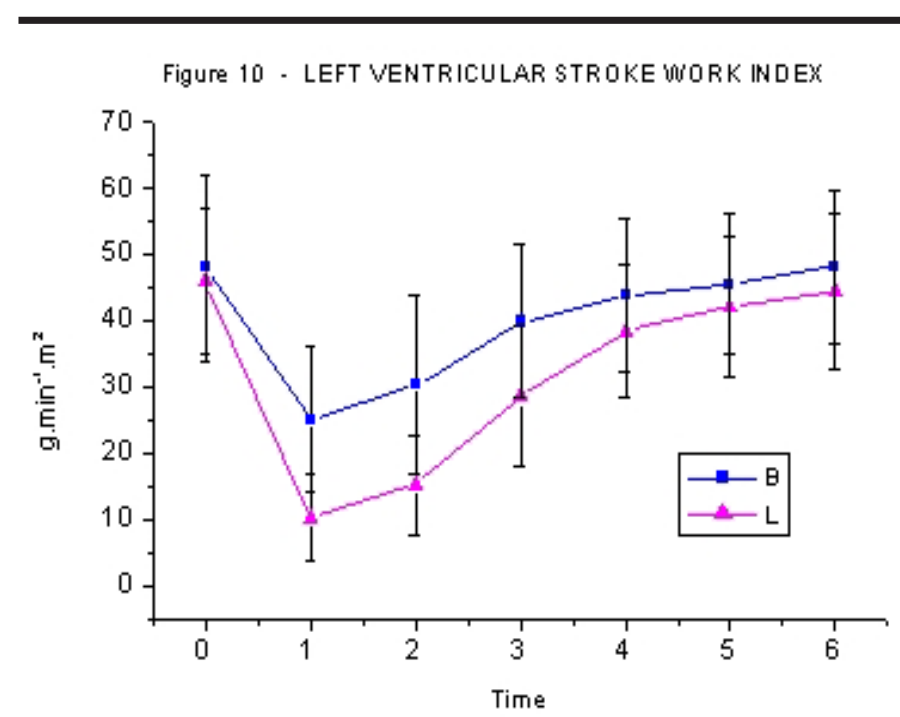

FIGURE 10 - Left Ventricular Stroke Work Index

TABLE 10 - Left ventricular stroke work index $\mathrm{g} \cdot \mathrm{min}^{-1} \cdot \mathrm{m}^{2}$

\begin{tabular}{llllllll}
\hline & $\mathrm{T}_{0}$ & $\mathrm{~T}_{1}$ & $\mathrm{~T}_{2}$ & $\mathrm{~T}_{3}$ & $\mathrm{~T}_{4}$ & $\mathrm{~T}_{5}$ & $\mathrm{~T}_{6}$ \\
$\mathrm{~B}$ & $48 \pm 14$ & $25.1 \pm 11.1$ & $30.3 \pm 13.4$ & $39.9 \pm 11.6$ & $43.8 \pm 11.6$ & $45.6 \pm 10.7$ & $48.2 \pm 11.6$ \\
$\mathrm{~L}$ & $46 \pm 11.1$ & $10.2 \pm 6.5$ & $15.2 \pm 7.6$ & $28.6 \pm 10.7$ & $38.4 \pm 10$ & $42.1 \pm 10.5$ & $44.5 \pm 11.8$ \\
\hline
\end{tabular}


Right ventricular stroke work index (figure and table 11) also showed a decrease after intoxication in both groups. The fall was more substantial in $\mathbf{L}$ and a significant difference between the groups was maintained from $T_{1}$ to $T_{4}$ and at $T_{6}(p=0.001)$. Values returned to those similar to resting values at $T_{3}$ in $\mathbf{B}$, and only at $T_{5}(p<0.001)$ in $\mathbf{L}$.

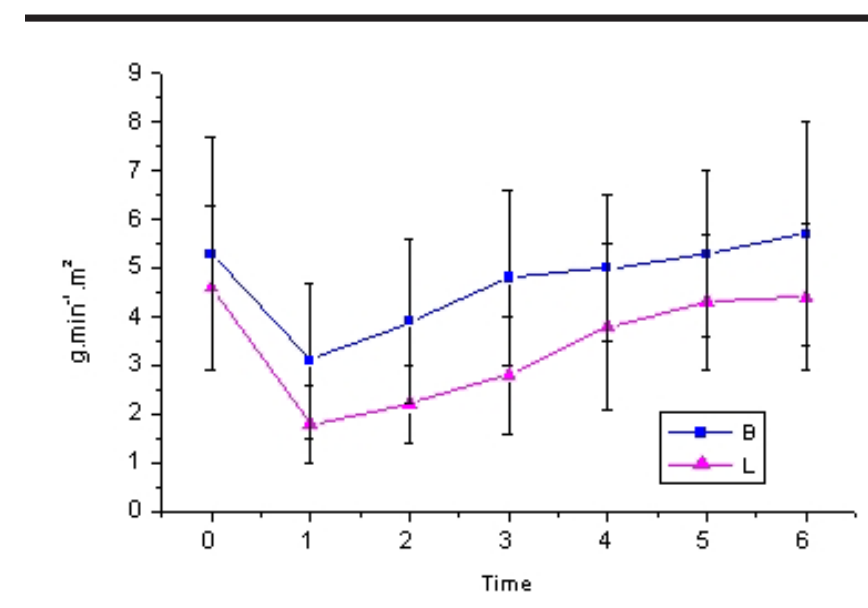

FIGURE 11 - Right Ventricular Stroke Work Index

TABLE 11 - Right ventricular stroke work index $\mathrm{g} \cdot \mathrm{min}^{-1} \cdot \mathrm{m}^{2}$

\section{Discussion}

The cardiac toxicity of local anesthetics is attributed to a blockade of sodium channels in the heart, leading to a prolonged conduction time with widening of QRS complexes, prolongation of PR interval, AV block and $\operatorname{arrythmias}^{14}$. Furthermore, these drugs have the ability to cause cardiac toxicity by altering mitochondrial metabolism in cardiac cells and thus alter inotropism ${ }^{15}$. The $\mathrm{S}(-)$ isomer may be less cardiotoxic due to its lower affinity for cardiac sodium channels, in comparison to the $\mathrm{R}(+)$ isomer, as demonstrated in guinea pigs ${ }^{16}$. Such data, however, should be viewed with some reservation before it can be extrapolated to humans. The overall pharmacodynamic events seen with levobupivacaine are similar to those seen with bupivacaine but we have found quantitative differences ${ }^{17}$. Other authors have also compared levobupivacaine, racemic bupivacaine and ropivacaine in animals, demonstrating that levobupivacaine had a similar ${ }^{18}$ or even greater toxicity. ${ }^{19,20}$ In agreement with those authors, our results showed that levobupivacaine had greater hemodynamic repercussions on a swine model of acute intoxication, simulating what may occur after accidental intravenous injections of local anesthetics during local and regional anesthesia. Evidence of toxicity was shown in the significantly more important decrease in cardiac index, mean arterial pressure, heart rate and left ventricular stroke work index. In a more homogeneous model, these results confirm those previously obtained with a preparation containing $75 \%$ of the levorotatory isomer in $\operatorname{dogs}^{21}$. Results obtained in animals should be viewed cautiously and prudence is of the essence when extrapolating these data to humans. However, further comprehensive studies must be encouraged, since results of this nature are not the first to be observed. Accidental injections of high doses of local anesthetics and toxic reactions during local and regional anesthesia have decreased in the last 30 years, falling from 0.2 to $0.01 \%$. Peripheral nerve blocks still account for the majority of these cases $(7.5 \text { per } 10.000)^{22}$. Such considerations should intensify new efforts to discover drugs and techniques that enable us to achieve a significantly low morbidity and mortality rate, protecting patients from the undesirable and unpredictable effects of local and regional anesthesia techniques with high doses of local anesthetics.

\section{Conclusion}

Levobupivacaine was more cardiotoxic than racemic bupivacaine when large doses were injected intravenously in swine, as may accidentally occur during local and regional anesthesia. 


\section{References}

1. Groban L, Deal DD, Vernon JC, James RL, Butterworth John - Cardiac resuscitation after incremental overdosage with lidocaine, bupivacaine, levobupivacaine, and ropivacaine in anesthetized dogs. Anesth Analg. 2001;92:37-43.

2. Chang DH-T, Ladd LA, Copeland S, Iglesias MA, Plummer JL, Mather LE -Direct cardiac effects of intracoronary bupivacaine, levobupivaciane and ropivacaine in the sheep. Br J Pharmacol. 2001;132:64958.

3. Albright GA - Cardiac arrest following regional anesthesia with etidocaine or bupivacaine. Anesthesiology. 1979;51:285-7.

4. Ohmura S, Kawada M, Ohta T, Yamamoto K, Kobayashi $\mathrm{T}$ - Systemic toxicity and resusciation in bupivacaine, levobupivacaine, or ropivacaine-infused rats. Anesth Analg. 2001;93:743-8.

5. Åberg G - Toxicological and local anesthetic effects of optically active isomers of two local anesthetic compounds. Acta Pharmacol Toxicol. 1972;31:273-86.

6. Luduena FP, Bogado EF, Tullar BF - Optical isomers of mepivacaine and bupivacaine. Arch Int Pharmacodyn. 1972;200:359-69.

7. Foster RH, Markham A - Levobupivacaine. A review of its pharmacology and use as a local anesthetic. Drugs. 2000;59:551-79.

8. Bardsley H, Gristwood R, Baker H, Watson N, Nimmo W - A comparison of the cardiovascular effects of levobupivacaine and rac-bupivacaine following intravenous administration to healthy volunteers. $\mathrm{Br}$ Clin Pharmacol. 1998;46:245-9.

9. Lyons G, Columb M, Wilson RC, Johnson RV - Epidural pain relief in labour:potencies of levobupivacaine and racemic bupivacaine. Br J Anaesth. 1998;81:899-901.

10. Héctor JL, Columb MO - The relative motor blocking potencies of bupivacaine and levobupivacaine in labour. Anesth Analg. 2003;97:1509-13.

11. Smith AC, Ehler WJ, Swindle MMl - Anesthesia and analgesia in swine. In: Kohn DF, Wixson SK, White WJ, Benson JG - Anesthesia and Analgesia in
Laboratory Animals, $1^{\text {st }}$ ed., New York, Academic Press, 1997;313-36.

12. Ettinger SJ: Textbook of Veterinary Internal Medicine, vol. 1, $1^{\text {st }}$ ed., Philadelphia, WB Saunders Co., 1975:146.

13. Lefrant JY, Muller L, de La Coussaye JE, Lalourcey L, Ripart J, Peray PA, Mazoit X, Dauzat M, Sassine A, Eledjam JJ - Hemodynamic and cardiac electrophysiologic effects of lidocainebupivacaine mixture in anesthetized and ventilated piglets. Anesthesiology. 2003;98:96-103.

14. Clarkson CW, Hondeghem LM - Mechanism for bupivacaine depression of cardiac conduction: fast block of sodium channels during the action potential with slow recovery from block during diastole. Anesthesiology. 1985;62:396-405.

15. Butherworth JF, Brownlown RC, Leith JP, Prielipp RC, Cole LR - Bupivacaine inhibits cyclic 3,5 adenosine monophosphate production. A possible contribution factor to cardiovascular toxicity. Anesthesiology. 1993;79:88-95.

16. Valenzuela C, Snyders DJ, Bennett PB, Tamargo J, Hondeghem LM - Stereoselective block of cardiac sodium channels by bupivacaine in guinea pig ventricular myocytes. Circulation. 1995;92:3014-24.

17. Huang YF, Prior ME, Mather LE, Veering B Cardiovascular and central nervous system effects of intravenous levobupivacaine and bupivacaine in sheep. Anesth Analg. 1998;86:797-804.

18. Royse CF, Royse AG - The myocardial and vascular effects of bupivacaine, levobupivacaine, and ropivacaine using pressure volume loops. Anesth Analg. 2005;101:679-87.

19. Masuda R, Takeda S, Yoshii S, Nagano H, Tomaru TLevobupivacaine exerts the most detrimental effect on the cardiovascular system among enantiomers of bupivacaine in anesthetized dogs. Anesthesiology. 2004;101:A652.

20. Jung CW, Lee KH, Choe YS, Bae SS - Comparison of resuscitative effect of insulin between bupivacaine and levobupivacaine induced cardiovascular collapse in dogs. Anesthesiology. 2004;101:A649. 
21. Udelsmann A, Munhoz DC, Silva WA, Moraes AC, Marcondes G - Comparação entre os efeitos hemodinâmicos da intoxicação aguda com bupivacaína racêmica e a mistura com excesso enatiomérico de 50\% (S75-R25). Estudo experimental em cães. Rev Bras Anestesiol. 2006;56:391-401.

22. Cox B, Durieux ME, Marcus MA - Toxicity of local anesthetics. Best Pract Res Clin Anaesthesiol. 2003; 17:111-36.

\section{Correspondence:}

Artur Udelsmann Financial source: FAEPEX, UNICAMP

Dept. Anesthesiology FCM / UNICAMP

Av. Prof. Atílio Martini, 213

13083-830 Campinas-São Paulo, Brazil

Phones: (19) 9105.8304 / 3521.9560

Received: August 29, 2007

audelsmann@yahoo.com.br

Review: October 30, 2007

Accepted: November, 26, 2007

\section{How to cite this article}

Udelsmann A, Lorena SERS, Girioli SU, Silva WA, Moraes AC, Andreollo NA. Hemodynamic effects of local anesthetics intoxication. experimental study in swine with levobupivacaine and bupivacaine. Acta Cir Bras. [serial on the Internet] 2008 Jan-Feb;23(1). Available from URL: http://www.scielo.br/acb 